\title{
ANALISIS FISIK, KIMIA, DAN ORGANOLEPTIK KUE BAY TAT BERBASIS TEPUNG TEMPE
}

\section{PHYSICAL, CHEMICAL, AND ORGANOLEPTIC ANALYSIS OF BAY TAT CAKES BASED ON TEMPE FLOUR}

\author{
Rio Taufik Rinaldo \\ PT Agro Muko \\ Desa Air Dikit Muko-muko Utara, Bengkulu Utara, Provinsi Bengkulu \\ Email : riotaufik@gmail.com
}

\begin{abstract}
ABSTRAK
Tempe merupakan makanan yang terbuat dari kacang kedelai yang difermentasi. Tempe mempunyai daya simpan yang singkat dan akan segera membusuk selama penyimpanan sehingga perlu diolah menjadi tepung, tepung tempe adalah tepung yang terbuat dari tempe yang dikukus lalu dijemur sampai kering dan digiling. Penelitian ini bertujuan untuk mengetahui pengaruh subsitusi tepung tempe terhadap mutu kue bay tat

Metode dalam penelitian ini meliputi proses pembuatan tepung tempedan kue bay tat. Perlakuan yang digunakan adalah variasi perbandingan tepung terigu dan tepung tempe. Analisis penelitian ini meliputi kandungan protein, kadar lemak, kadar air, tekstur dan sifat organoleptikkue bay tat.

Hasil analisis menunjukkan kadar protein kue bay tat berkisar 2,65\% - 3,13\%, kadar air berkisar antara 13,30\% - 17,13\% dan kadar lemak berkisar 5,51\% - 6,59\%. Hasil analisisteksturyaitu 1,2 $\mathrm{mm}-2,1 \mathrm{~mm}$ dan hasil uji organoleptik terhadap warna, rasa, aroma dan kenampakan kue bay tat menunjukkan perbedaan yang nyata.
\end{abstract}

Kata Kunci: tepung tempe, kue bay tat, substitusi

ABSTRACT

Tempe is a food made from fermented soy beans. Tempe has a short shelf life and will soon rot during storage so it needs to be processed into flour, tempe powder is a flour made from steamed tempe and then dried in the sun to dry and ground. This study aims to determine the influence of tempe flour substitution on the quality of bay tat cake

Methods in this research include the process of making tempe powder and bay tat cake. The treatment used was variation of wheat flour and tempe flour. Analysis of this study include protein content, fat content, water content, texture and organoleptic properties of bay tat cake.

The results showed that the protein content of bay tat cake ranged from $2.65 \%$ $3.13 \%$, water content ranged from $13.30 \%$ - $17.13 \%$ and fat content ranged from $5.51 \%$ $6.59 \%$. The texture analysis result is $1.2 \mathrm{~mm}-2,1 \mathrm{~mm}$ and organoleptic test result to the color, flavor, aroma and appearance of bay tat cake show the real difference.

Keywords: tempe flour, bay tat cake,, substitution 


\section{PENDAHULUAN}

Indonesia merupakan negara produsen tempe terbesar di dunia dan menjadi pasar kedelai terbesar di Asia. Tempe merupakan makanan yang terbuat dari kacang kedelai yang difermentasi. Masyarakat luas menjadikan tempe sebagai sumber protein nabati. Adapun keunggulan tempe yaitu cita rasanya lebih disukai dan dapat dikembangkan menjadi berbagai produk dengan cita rasa beragam, sehingga tingkat penerimaan masyarakat semakin tinggi. Selama proses fermentasi kadar protein hanya berubah sedikit. Tempe mempunyai daya simpan yang singkat dan akan segera membusuk selama penyimpanan. Hal ini disebabkan oleh proses fermentasi lanjut yang menyebabkan degradasi protein lebih lanjut, oleh karna itu perlu adanya usaha peningkatan umur simpan tempe.

Pengolahan tempe menjadi tepung tempe dapat memperpanjang umur simpan tempe. Tepung tempe adalah tepung yang terbuat dari tempe yang dikukus lalu dijemur sampai kering dan digiling menjadi tepung. Tepung tempe dapat digunakan sebagai pengganti tepung terigu. Tepung terigu merupakan komponen utama pembuatan kue bay tat. Bay tat merupakan salah satu makanan khas Bengkulu. Oleh karna itu, peneliti tertarik untuk mengetahui pengaruh variasi perbandingan tepung terigu dan tepung tempe terhadap kadar protein, lemak, air dan sifat organoleptik dari kue bay tat yang dihasikan.

\section{METODE PENELITIAN}

\section{Bahan dan Alat}

Bahan yang digunakan adalah tempe, margarine, gula, telur, tepung terigu, santan, soda, selai nanas, dan bahan-bahan untuk analisis. Alat-alat yang digunakan adalah blender, timbangan, baskom, oven, sendok, kompor, pisau, dan alat-alat untuk analisis.

\section{Cara Penelitian}

\section{Proses Pembuatan Tepung Tempe}

1) Tempe segar di iris dengan ukuran $1 \times 0,5 \times 0,5 \mathrm{~cm}$

2) Tempe di jemur selama 3 hari

3) Tempe yang kering, digiling hingga halus

4) Tepung tempe diayak

\section{Proses Pembuatan Kue Bay Tat}

1) Santan kelapa $100 \mathrm{ml}$ dan gula pasir 75 gr dimasak selama 10 menit

2) Santan kelapa dan gula pasir yang telah dimasak didinginkan

3) Santan kelapa dan gula yang telah dingin, dicampurkan soda $1 \mathrm{gr}$, vanilla 1 gr, garam 1 gr, 1 butir telur, margarine 50 gr dan penambahan tepung terigu dan tepung tempe dengan 
perbandingan $(50 \mathrm{gr}: 50 \mathrm{gr}, 80 \mathrm{gr}$ : 20 gr, 60 gr : 40 gr, 40 gr : 60 gr, 20 gr : 80 gr) diadon hingga kalis.

4) Adonan dicetak, dan diberikan selai nanas selanjutnya di oven selama 37-38 menit dengan suhu $125{ }^{\circ} \mathrm{C}$

5) Kue bay tat yang telah masak di angkat dan didinginkan

Perlakuan yang dilakukan dalam penelitian yaitu

T1K1 Tepung Terigu : Tepung Tempe $=80: 20$

T2K1 Tepung Terigu : Tepung Tempe $=60: 40$

T3K1 Tepung Terigu : Tepung Tempe $=40: 60$

T4K1 Tepung Terigu : Tepung Tempe $=20: 80$

\section{Analisis Penelitian.}

Analisis yang dilakukan dalam penelitian ini adalah :

1) Analisis Kadar Protein (Sudarmadji dkk, 1996)

2) Analisis Kadar Lemak (Sudarmadji, et al.,1989)

3) Analisis Kadar Air (Sudarmadji dkk, 1997)
4) Analisis Tekstur (Yuwono dan Susanto, 2001).

5) Uji Organoleptik (Soekarta, 2008) Analisis uji organoleptik dilakukan untuk mengetahui tingkat kesukaan konsumen terhadap kue bay tat tempe dengan parameter penilaian meliputi warna, rasa, aroma dan kenampakan.

\section{Rancangan Percobaan}

Dalam penelitian ini rancangan percobaan yang dilakukan yaitu Rancangan Acak Lengkap (RAL) dengan 3 ulangan.

\section{HASIL DAN PEMBAHASAN}

\section{Kandungan Protein Kue Bay Tat}

Protein merupakan suatu zat makanan yang amat penting bagi tubuh, karena zat ini disamping sebagai bahan bakar dalam tubuh juga berfungsi sebagai zat pembangun dan pengatur.Kekurangan konsumsi protein pada masa pertumbuhan dapat menyebabkan terganggunya pertumbuhan badan.Nilai rerata analisa kandungan protein kue bay tat dengan perlakuan subtitusi tepung tempe ( 20,40 , 50, 60 dan 80) dapat dilihat pada tabel 1 . 
Tabel 1. Hasil Analisis Kandungan Protein Kue Bay Tat

\begin{tabular}{|c|c|}
\hline Perlakuan & Kandungan Protein (\%) \\
\cline { 1 - 1 } Tepung Terigu : Tepung Tempe & \\
\hline $80: 20$ & $2,74^{\mathrm{b}}$ \\
\hline $60: 40$ & $2,65^{\mathrm{c}}$ \\
\hline $50: 50$ & $2,67^{\mathrm{c}}$ \\
\hline $40: 60$ & $3,09^{\mathrm{a}}$ \\
\hline $20: 80$ & $3,11^{\mathrm{a}}$ \\
\hline
\end{tabular}

Ket :Angka yang diikuti oleh kode huruf yang berbeda menunjukkanadanya perbedaan yang nyata pada taraf signifikansi $5 \%$.

Berdasarkan tabel 1. hasil analisis kandungan protein kue bay tat dengan perlakuan subtitusi tepung tempe (80 gr dan 60 gr) tidak menunjukkan perbedaan yang nyata akan tetapi berbeda nyata dengan perlakuan subtitusi tepung tempe (20 gr ,40 gr dan 50 gr), perlakuan subtirusi tepung tempe (40 gr dan 50 gr) tidak menunjukkan perbedaan yang nyata tetapi berbeda nyata terhadap perlakuan subtitusi tepung tempe (20 gr, 60 gr dan 80 gr) sedangkan perlakuan dengan subtitusi tepung tempe $\left(\begin{array}{lll}20 & \text { gr }\end{array}\right)$ menunjukkan perbedaan yang nyata pada perlakuan subtitusi tepung tempe (40 gr, 50 gr, 60 gr dan 80 gr) pada taraf signifikan 5\%. Rerata kandungan protein kue bay tat dengan perlakuan subtitusi tepung tempe 80 gr kandungan protein sebesar $3,11 \%$, subtitusi tepung tempe 60 gr kandungan protein 3,09\%, subtitusi tepung tempe 50 gr kandungan protein 2,67\%, subtitusi tepung tempe $40 \mathrm{gr}$ kandungan protein $2,65 \%$ dan perlakuan subtitusi tepung tempe 20 gr kandungan protein sesesar 2,74\%. Subtitusi tepung tempe pada mempengaruhi kandungan protein kuy bay tata yang dihasilkan.

Hasil analisis kandungan tepung tempe dengan perlakuan subtitusi tepung tempe yaitu 80 gr menunjukkan kandungan protein kue bay tat yang paling tinggi jika dibandingkan dengan perlakuan subtitusi tepung tempe 60, 50, 40 dan 20. Hal ini disebabkan kandungan protein tepung tempe $(46,1 \%)$ lebih tinggi dibandingkan tepung terigu (10\%-11,5\%). Tingginya kandungan protein pada tepung tempe karena proses fermentasi, fermentasi yang terjadi pada tempe berfungsi untuk mengubah senyawa makromolekul komplek yang terdapat pada kedelai (seperti protein, lemak, dan karbohidrat) menjadi senyawa yang lebih sederhana seperti peptida, asam amino, asam lemak dan monosakarida (Sutomo, 
2008). Silitonga ( 2014 ) menyatakan bahwa penambahan tepung tempe berpengaruh nyata terhadap kandungan protein kukis.Semakin tinggi penambahan tepung tempe menunjukkan kandungan protein yang semakin tinggi karna tempe merupakansalah satu sumber protein nabati. MenurutPersatuan Ahli Gizi Indonesia (2009),tempe mengandung protein sebesar 20,8 g. Hasil analisis kandungan protein kue bay tat dengan perlakuan penambahan tepung tempe 80 gr yaitu $3,11 \%$. Jadi, perbandingan tepung terigu dan tepung tempe $(20: 80)$ merupakan hasil yang paling baik dari segi kandungan protein.

\section{Kadar Air Kue Bay Tat}

Air merupakan salah satu karakteristik yang penting bagi bahan pangan, kandungan air pada bahan pangan dapat mempengaruhi penampakan dan cita rasa makanan (Winarno, 2004).Kadar air merupakan banyaknya air yang terkandung dalam bahan yang dinyatakan dalam persen.Kadar air juga salah satu karakteristik yang sangat penting pada bahan pangan, karena air dapat mempengaruhi penampakan, tekstur, dan citarasa pada bahan pangan. Kadar air dalam bahan pangan ikut menentukan kesegaran dan daya awet bahan pangan tersebut, kadar air yang tinggi mengakibatkan mudahnya bakteri, kapang, dan khamir untuk berkembang biak, sehingga akan terjadi perubahan pada bahan pangan (Winarno, 1997).Nilai rerata analisa kandungan kadar air kue bay tat dengan perlakuan subtitusi tepung tempe $(20,40,50,60$ dan 80$)$ dapat dilihat pada tabel 2.

Tabel 2. Hasil Analisis Kadar Air Kue Bay Tat

\begin{tabular}{|c|c|}
\hline Perlakuan & Kandungan Kadar Air (\%) \\
\cline { 1 - 1 } Tepung Terigu : Tepung Tempe & \\
\hline $80: 20$ & $13,30^{\mathrm{e}}$ \\
\hline $60: 40$ & $14,18^{\mathrm{d}}$ \\
\hline $50: 50$ & $17,13^{\mathrm{a}}$ \\
\hline $40: 60$ & $17,03^{\mathrm{b}}$ \\
\hline $20: 80$ & $16,09^{\mathrm{c}}$ \\
\hline
\end{tabular}

Ket :Angka yang diikuti oleh kode huruf yang berbeda menunjukkanadanya perbedaan yang nyata pada taraf signifikansi $5 \%$. 
Berdasarkan tabel 2. hasil analisis kandungan kadar air kue bay tata dengan perlakuan subtitusi tepung tempe (20gr, 40 gr, 50 gr, 60 gr dan 80 gr) menunjukkan perbedaan yang nyata pada taraf signifikan 5\%. Rerata hasil analisisi kue bay tat dengan perlakuan subtitusi tepung tempe 20 gr kandungan kadar air $13,30 \%$, perlakuan subtitus tepung tempe 40 gr kandungan kadar air $14,18 \%$,subtitusi tepung tempe 50 gr kandungan kadar air 17,13\%, subtitusi tepung tempe 60 gr kandungan kadar air $17,03 \%$ dan subtitusi tepung tempe $80 \mathrm{gr}$ kandungan kadar air 16,09\%.

Hasil analisis kandungan kadar air kue bay tat dengan perlakuan subtitusi tepung tempe 50 gr menunjukkan kandungan kadar air tertinggi jika dibandingkan dengan perlakuan subtitusi tepung tempe 20 gr, 40 gr, 60 gr dan 80 gr. Kandungan kadar air pada kue bay tat dengan perlakuan subtitusi tepung tempe 50 gr menunjukkan kandungan kadar air tertinggi yaitu $17,13 \%$. Hal ini disebabkan kandungan kadar air tepung terigu lebih tinggi jika dibandingkan dengan kandungan kadar air tepung tempe. Kandungan kadar air tepung terigu sebesar $12 \%$ (Direktorat Gizi Depkes RI, 1979) kadar air tepung tempe yaitu 4,0\% (Pusat Penelitian Kimia-LIPI 2001).
Seharunya dalam penelitian ini kadar air yang tertinggi perlakuan dengan penggunaan tepung terigu $80 \mathrm{gr}$, tetapi hasil menunjukkan kadar air yang terendah yaitu $13,30 \%$. Hasil analisis menunjukkan kandungan kadar air tertinggi pada perlakuan perbandingan tepung terigu dan tempe (50 gr : 50 gr) yaitu $17,13 \%$.

\section{Kadar Lemak Kue Bay Tat}

Lemak merupakan makanan sumber energi yang lebih efektif dibandingkan karbohidrat dan protein.Satu gram lemak dapat menghasilkan 9 kalori, sedangkan karbohidrat dan protein hanya menghasilkan 4 kalori.Lemak merupakan polimer yang tersusun dari unsur-unsur karbon, hydrogen, dan oksigen.Lemak mempunyai sifat tidak larut dalam air.Struktur dasar lemak adalah triester dan gliserol yang dinamakan trigliserida.Kadar lemak tepung sangat berhubungan erat dengan ketahanan produk olahan yang berbahan dasar tepung terhadap ketengikan karena oksidasi lemak. Nilai rerata analisa kandungan kadar air kue bay tat dengan perlakuan subtitusi tepung tempe (20, 40, 50, 60 dan 80) dapat dilihat pada tabel 3. 
Tabel 3. Hasil Analisis Kadar Lemak Kue Bay Tat

\begin{tabular}{|c|c|}
\hline Perlakuan & Kandungan Kadar Lemak (\%) \\
\hline Tepung Terigu : Tepung Tempe & $6,27^{\mathrm{b}}$ \\
\hline $80: 20$ & $6,25^{\mathrm{b}}$ \\
\hline $60: 40$ & $6,59^{\mathrm{a}}$ \\
\hline $50: 50$ & $5,51^{\mathrm{c}}$ \\
\hline $40: 60$ & $5,58^{\mathrm{c}}$ \\
\hline $20: 80$ & \\
\hline
\end{tabular}

Ket :Angka yang diikuti oleh kode huruf yang berbeda menunjukkanadanya perbedaan yang nyata pada taraf signifikansi $5 \%$.

Berdasarkan tabel 3. hasil analisis kandungan kadar lemak kue bay tat dengan perlakuan subtitusi tepung tempe (50 gr) menunjukkan perbedaan yang nyata terhadap perlakuan subtitusi tepung tempe (20 gr, $40 \mathrm{gr}, 60 \mathrm{gr}$ dan 80 gr), sedangkan perlakuan subtitusi tepung tempe (20 gr dan 40 gr) menunjukkan perbedaan yang nyata terhadap perlakuan subtitusi tepung tempe (50 gr, 60 gr dan 80 gr) dan perlakuan dengan subtitusi tepung tempe $\left(\begin{array}{lllll}60 & \text { gr } & \text { dan } & 80 & \text { gr }\end{array}\right)$ menunjukkan perbedaan yang nyata terhadap perlakuan subtitusi tepung tempe (50 gr, 20 gr dan 40 gr) pada taraf singnifikan $5 \%$.

Rerata hasil analisis kandungan kadar lemak kue bay tat dengan perlakuan subtitusi tepung tempe 50 gr dengan kadar lemak $6,59 \%$, subtitusi tepung tempe 20 gr dengan kadar lemak 6,27\%, subtitusi tepung tempe 40 gr dengan kadar lemak
6,25 gr, perlakuan subtitusi tepung tempe 60 gr dengan kadar lemak 5,51\% dan subtitusi tepung tempe 80 gr dengan kadar lemak 5,58\%. Hasil analisis kandungan kadar lemak kue bay tat dengan perlakuan subtitusi tepung tempe $50 \mathrm{gr}$ menunjukkan kandungan lemak tertinggi yaitu 6,59\%. Tingginya kandungan kadar lemak pada kue bay tat dapat di sebabkan dengan penggunaan tepung tempe pada penggolahan kue bay tat, kandungan kadar lemak tepung tempe berkisar antara 22,7\% (Sunita Almatsier, 2009)

\section{Tekstur Kue Bay Tat}

Tekstur merupakan salah satu atribut penilaian sensori yang perlu diperhatikan dalam produk.Nilai rerata analisa kandungan tekstur kue bay tat dengan perlakuan subtitusi tepung tempe (20, 40, 50, 60 dan 80) dapat dilihat pada tabel 4 . 
Tabel 4. Hasil Analisis Tekstur Kue Bay Tat

\begin{tabular}{|c|c|}
\hline Perlakuan & Kandungan Tekstur (mm) \\
\hline Tepung Terigu : Tepung Tempe & \\
\hline $80: 20$ & $2,1^{\mathrm{a}}$ \\
\hline $60: 40$ & $1,4^{\mathrm{c}}$ \\
\hline $50: 50$ & $1,5^{\mathrm{b}}$ \\
\hline $40: 60$ & $1,5^{\mathrm{b}}$ \\
\hline $20: 80$ & $1,2^{\mathrm{d}}$ \\
\hline
\end{tabular}

Ket :Angka yang diikuti oleh kode huruf yang berbeda menunjukkanadanya perbedaan yang nyata pada taraf signifikansi $5 \%$.

Berdasarkan tabel 4. hasil analisis tekstur kue bay tat dengan perlakuan dengan subtitusi tempe $\left(\begin{array}{ll}20 & \text { gr }\end{array}\right)$ menunjukkan perbedaan nyata terhadap perlakuan subtitusi tepung tempe (40 gr, 50 gr, 60 gr dan 80 gr), perlakuan subtitusi tepung tempe (50 gr dan $60 \mathrm{gr}$ ) menujukkan tidak beda nyata akan tetapi berbeda nyata dengan perlakuan subtitusi tepung tempe (20 gr, 40 gr dan 80 gr), pada taraf singnifikasi $5 \%$. Rerata nilai tekstur kue bay tat dengan perlakuan subtitusi tepung tempe 100 gr dengan nilai tekstur $1,5 \mathrm{~mm}$, subtitusi 20 gr nilai tekstur 2,1 mm, subtitusi tepung tempe 40 gr dengan nilai tekstur $1,4 \mathrm{~mm}$, perlakuana subtitusi tepung tempe $60 \mathrm{gr}$ dengan nilai tekstur $1,5 \mathrm{~mm}$ dan perlakuan subtitusi tepung tempe 80 gr dengan nilai tekstur 1,2 $\mathrm{mm}$. berdasarkan hasil analisisi tekstur semakin tinggi nilai tekstur menunjukkan semakin lembut kue bay tat.

Hasil analisis kue bay tat dengan subtitusi tepung tempe 20 gr menunjukkan penilaian tekstur tertinggi yaitu 2,1 mm yang menunjukkan tekstur kue bay tat lembut. Setiap bahan makanan mempunyai sifat tekstur tersendiri terkandung pada keadaan fisik, ukuran dan bentuk sel yang dikandungnya. Penilaian terhadap tekstur dapat berupa kekerasan, elastisitas atau kerenyahan. Tekstur bay tat dapat disebabkan dengan penggunanan tepung terigu yang mengandung gluten atau glidin. Dimana tepung terigu mampu menyerap air dan dapat mencapai konsistensi adonan yang tepat untuk menghasilkan tekstur yang lembut.

\section{Organoleptik Warna Kue Bay Tat}

Warna merupakan salah satu aspek yang penting terhadap kualitas suatu produk makanan. Menurut Deman (1997), warna penting bagi banyak makanan, bersama bau rasa dan tekstur warna memegang peranan penting dalam hal penerimaan suatu makanan.Nilai rerata 
warna kue bay tat dengan perlakuan subtitusi tepung tempe (50 gr, $20 \mathrm{gr}, 40$ gr, 60 gr dan 80 gr) dapat dilihat pada tabel 5 .

Berdasarkan tabel 5 rerata uji organoleptik warna kue bay tat dengan perlakuan dengan subtitusi tepung tempe (60 gr) menunjukkan perbedaan yang nyata dengan perlakuan subtitusi tepung tempe (50 gr, 20 gr, 40 gr dan 80 gr, sedangkan perlakaun substitusi tepung tempe (20 gr, 40 gr, 50 gr dan 80 gr) tidak beda nyata pada taraf signifikasi $5 \%$. Rerata uji organoleptik dengan subtitusi tepung tempe $50 \mathrm{gr}$ dengan penilaian 1,95 berada pada skala suka, subtitusi tepung tempe 20 gr dengan penilaian 2,05 berada pada skala suka, perlakuan subtitusi tempe 40 gr dengan penilaian 2,20 berada pada skala suka, subtitusi tepung tempe $60 \mathrm{gr}$ dengan penilaian 2,50 berada pada skala suka dan perlakuan dengan subtitusi tepung tempe $80 \mathrm{gr}$ dengan penilaian 2,30 berada pada skala suka.

Hasil rerata uji organoleptik warna pada kue tata berdasarkan penilaian panelis berada pada skala suka.Secara visual faktor warna memegang peranan yang sangat penting kesan pertama yang didapatkan adalah warna.Warna kue bay tat yang dihasilkan yaitu kuning kecoklatan. Warna kue bay tat dipengaruhi oleh bahan baku yang digunakan seperti jenis tepung, telur dan essence. Kue bay tat tanpa subtitusikan tepung tempe menunjukkan warna yang lebih cerah jika dibandingkan dengan kue bay tat dengan subtitusi tepung tempe. Semakin tinggi subtitusi tepung tempe warna kue bay tat semakin kecoklatan. Hal ini disebabkan oleh warna tepung tempe yang kecoklatan dibandingkan tepung terigu. Tepung mempengaruhi warna dan flavor yaitu sebagai akibat dekstrinasi pati tepung selama pembakaran (Mc William, 1979).

\section{Organoleptik Rasa Kue Bay Tat}

Rasa timbul akibat adanya rangsangan kimiawi yang dapat diterima oleh indera pencicip atau lidah.Rasa adalah faktor yang mempengaruhi penerimaan produk pangan. Menurut deMan (1997), rasa umum disepakati bahwa hanya ada empat rasa dasar yaitu manis, pahit, masam dan asin. Kepekaan terhadap rasa terdapat pada kuncup rasa pada lidah.Hubungan antara struktur kimia suatu senyawa lebih mudah ditentukan dengan rasanya. Nilai rerata rasa kue bay tat dengan perlakuan subtitusi tepung tempe (50 gr, 20 gr, 40 gr, 60 gr dan 80 gr) dapat dilihat pada tabel

6. 
Tabel 5.Rerata Uji Organoleptik Warna Kue Bay Tat

\begin{tabular}{|c|c|}
\hline Perlakuan & Warna \\
\hline Tepung Terigu : Tepung Tempe & \\
\hline $80: 20$ & $2,05^{\mathrm{b}}$ \\
\hline $60: 40$ & $2,20^{\mathrm{ab}}$ \\
\hline $50: 50$ & $1,95^{\mathrm{b}}$ \\
\hline $40: 60$ & $2,50^{\mathrm{a}}$ \\
\hline $20: 80$ & $2,30^{\mathrm{ab}}$ \\
\hline
\end{tabular}

Ket :Angka yang diikuti oleh kode huruf yang berbeda menunjukkanadanya perbedaan yang nyata pada taraf signifikansi $5 \%$.Ket Skala : $1=$ sangat suka; $2=$ suka; $3=$ agak suka; $4=$ tidak suka; $5=$ sangat tidak suka

Tabel 6.Rerata Uji Organoleptik Rasa Kue Bay Tat

\begin{tabular}{|c|c|}
\hline Perlakuan & Rasa \\
\hline Tepung Terigu : Tepung Tempe & \\
\hline $80: 20$ & $2,10^{\mathrm{ab}}$ \\
\hline $60: 40$ & $2,15^{\mathrm{ab}}$ \\
\hline $50: 50$ & $1,90^{\mathrm{b}}$ \\
\hline $40: 60$ & $2,25^{\mathrm{ab}}$ \\
\hline $20: 80$ & $2,30^{\mathrm{a}}$ \\
\hline
\end{tabular}

Ket :Angka yang diikuti oleh kode huruf yang berbeda menunjukkanadanya perbedaan yang nyata pada taraf signifikansi $5 \%$.Ket Skala : $1=$ sangat suka; $2=$ suka; $3=$ agak suka; $4=$ tidak suka; $5=$ sangat tidak suka

Berdasarkan Tabel 6 rerata uji organoleptik rasa kue bay tat dengan perlakuan subtitusi tepung tempe (50 gr) menunjukkan perbedaan yang nyata terhadap perlakuan subtitusi tepung tempe (20 gr, 40 gr, 60 gr dan 80 gr), sedangkan perlakuan subtitusi tempe (20 gr, 40 gr, 60 gr dan 80 gr) menunjukkan tidak beda nyata pada taraf signifikasi 5\%. Rerata uji organoleptik rasa dengan subtitusi tepung tempe 50 gr dengan nilai 1,90 berada pada skala suka, subtitusi tepung tempe 20 gr dengan penilaian 2,10 berada pada skala suka, perlakuan dengan subtitusi tepung tempe 40 gr dengan peniaian 2,15 berada pada skala suka, subtiusi tepung tempe 60 gr dengan penilaian 2,25 berada pada skala suka dan perlakuan subtitusi tepung tempe 80 gr dengan nilai 2,30 berada pada skala suka.

Hasil rerata uji organoleptik terhada rasa kue bay tat dengan semakin 
tinggi subtitusi tepung tempe maka penilaian panelis terhadap rasa semakin tinggi berada pada skala suka. Rasa dinilai dengan adanya tanggapan rangsanga kimiawi oleh indra pencicip (lidah), dimana akhirnya kesatuan interaksi antara sifat-sifat aroma, rasa dan tekstur merupakan keseluruhan rasa makanan yang dinilai (Nasution, 1990). Menurut Inayati (1991) subtitusi tepung tempe $30 \%$ dari total tepung yang digunakan dalam pembuatan biskuit sudah menunjukkan rasa yang kurang disukai. Tepung tempe mempunyai rasa yang agak pahit (getir), yang kemungkinan oleh adanya peptide-peptida protein dengan rasa pahit.

\section{Organoleptik Aroma Kue Bay Tat}

Aroma merupakan salah satu faktor yang menentukan kelezatan bahan makanan cita rasa dari bahan pangan sesungguhnya terdiri dari tiga komponen, yaitu bau, rasa dan rangsangan mulut.Bau yang dihasilkan dari makanan banyak menentukan kelezatan bahan pangan tersebut.Dalam hal bau lebih banyak sangkut pautnya dengan alat panca indera penciuman. Menurut Kartika (1988), Pengujian terhadap aroma di industri pangan merupakan hal yang dianggap penting karena dengan cepat dapat memberikan hasil penilaian terhadap produk tentang diterima atau tidaknya produk tersebut oleh konsumen. Selain itu juga aroma dipakai sebagai indikator terjadinya kerusakan produk.Nilai rerata aroma kue bay tat dengan perlakuan subtitusi tepung tempe (20, 40, 50, 60 dan 80) dapat dilihat pada tabel 7.

Tabel 7.Rerata Uji Organoleptik Aroma Kue Bay Tat

\begin{tabular}{|c|c|}
\hline Perlakuan & Aroma \\
\cline { 1 - 1 } Tepung Terigu : Tepung Tempe & \\
\hline $80: 20$ & $2,00^{\mathrm{ab}}$ \\
\hline $60: 40$ & $2,30^{\mathrm{ab}}$ \\
\hline $50: 50$ & $1,95^{\mathrm{b}}$ \\
\hline $40: 60$ & $2,10^{\mathrm{ab}}$ \\
\hline $20: 80$ & $2,40^{\mathrm{a}}$ \\
\hline
\end{tabular}

Ket :Angka yang diikuti oleh kode huruf yang berbeda menunjukkanadanya perbedaan yang nyata pada taraf signifikansi $5 \%$.Ket Skala : $1=$ sangat suka; $2=$ suka; $3=$ agak suka; $4=$ tidak suka; $5=$ sangat tidak suka 
Berdasarkan tabel 7 rerata uji organoleptik kue bay tat denganperlakuan subtitusi tepung tempe $\left(\begin{array}{lll}50 & \text { gr }\end{array}\right)$ menunjukkan perbedaan yang nyata terhadap perlakuan subtitusi tepung tempe (20 gr, 40 gr, 60 gr dan 80 gr), sedangkan perlakuan subtitusi tepung tempe (20 gr, $40 \mathrm{gr}, 60 \mathrm{gr}$ dan $80 \mathrm{gr}$ ) tidak menunjukkan perbedaan yang nyata pada taraf signifikasi 5\%. Hasil rerata uji organoleptik aroma kue bay tat dengan perlakuan subtitusi tepung tempe $50 \mathrm{gr}$ dengan penilaian 1,95 berada pada skala suka, subtitusi tepung tempe 20 gr dengan penilaian 2,00 berada pada skala suka, perlakuan subtitusi tepung tempe $40 \mathrm{gr}$ dengan penilaian 2,30 berada pada skala suka, perlakuan subtitusi tepung tempe 60 gr dengan penilain 2,10 berada pada skala suka dan perlakuan subtitusi 80 gr dengan penilain 2,40 bearda pada skala suka.

Hasil penialian terhadap aroma kue bay tat dengan semakin tinggi penambahan tepung tempe menunjukkan penilain semakin tinggi berada pada skala suka. Aroma adalah bau yang ditimbulkan oleh rangsangan kimia yang tercium oleh syaraf-syraf yang berada pada rongga hidung ketika makanna masuk ke mulut (Peckham, 1969). Aroma kue bay tat dapat dipengaruhi oleh shortening, telur dan jenis tepung yang digunakan. Karena shortening dan telur diberikan dalam jumlah yang sama maka jenis tepunglah yang mempengaruhi terhadap aroma kue bay tat.

\section{Organoleptik Kenampakan Kue Bay Tat}

Kriteria penampakan merupakan parameter organoleptik yang cukup penting dinilai panelis. Hal ini disebabkan jika kesan kenampakan baik dan disukai, maka panelis akan melihat parameter lainnya (aroma, tekstur dan rasa). Nilai rerata kenampakan kue bay tat dengan perlakuan subtitusi tepung tempe $(20,40$, 50, 60 dan 80) dapat dilihat pada tabel 8 .

Berdasarkan Tabel 8 rerata uji oerganoeptik kenampakan kue bay tat dengan perlakuan dengan subtitusi tepung tempe (20 gr) menunjukan pernedaan yang nyata terhadap perlakuan subtitusi tepung tempe (40 gr, 50 gr, 60 gr dan 80 gr) sedangkan perlakaun substitusi tepung temp (50 gr, 40 gr, 60 gr dan 80 gr) tidak beda nyata pada taraf singnifikansi $5 \%$. Rerata nilai kenampakan subtitusi tepung tempe 50 gr dengan nilai 2,20 berada pada skala suka, subtitusi tepung tempe 20 gr dengan nilai 2,00 berada pada skala suka, subtitusi tepung tempe 40 gr dengan penilaian 2,35 berada pada skala suka, perlakuan subtitusi tepung tempe $60 \mathrm{gr}$ dengan penilaian 2,30 berada pada skala suka, dan perlakuan subtitusi tepung tempe 80 gr dengsn penilaian 2,40 berada pada skala suka. 
Tabel 8.Rerata Uji Organoleptik Kenampakan Kue Bay Tat

\begin{tabular}{|c|c|}
\hline Perlakuan & Kenampakan \\
\hline Tepung Terigu : Tepung Tempe & \\
\hline $80: 20$ & $2,00^{\mathrm{b}}$ \\
\hline $60: 40$ & $2,35^{\mathrm{a}}$ \\
\hline $50: 50$ & $2,20^{\mathrm{ab}}$ \\
\hline $40: 60$ & $2,30^{\mathrm{ab}}$ \\
\hline $20: 80$ & $2,40^{\mathrm{a}}$ \\
\hline
\end{tabular}

Ket :Angka yang diikuti oleh kode huruf yang berbeda menunjukkanadanya perbedaan yang nyata pada taraf signifikansi 5\%.Ket Skala : 1= sangat suka; 2 = suka; $3=$ agak suka; $4=$ tidak suka; $5=$ sangat tidak suka

Rerata nilai uji organoleptik kenampakan kue bay tat dengan semakin tinggi subtitusi tepung tempe penilaian panelis semakin tinggi berada pada skala suka. Kenampakan juga mempengaruhi nilai konsumen, meskipin kenampakan tidak menentukan tingkat kesukaan konsumen secara mutlak. Keseragaman dan keutuhan suatu produk tentunya akan menarik panelis dan lebih disukai jika dibandingkan dengan produk yang beragam dan tidak utuh (Soekarto, 1985) .Nilai rerata kenampakan kue bay tat cenderung disukai karena penampakan permukana kue bay tat yang utuh. Warna kuning kecoklatan hingga coklat di pengaruhi oleh penambahan tepung tempe dimana warna tepung tempe yang dihasilkan agak kecoklatan.

\section{KESIMPULAN}

Hasil analisis kadar protein kue bay tat yang paling tinggi pada perlakuan subsitusi tepung terigu dan tepung tempe 20 gr : 80 gr yaitu 3,12\%, sedangkan kadar protein terendah pada perlakuan subsitusi tepung terigu dan tepung tempe 60 gr : 40 gr yaitu 2,65\%. Hal ini dipengaruhi tingginya kandungan protein dari tepung tempe. Hasil analisis kadar air kue bay tat yang tertinggi pada perlakuan subsitusi tepung terigu dan tempe $50 \mathrm{gr}$ : 50 gr yaitu $17,13 \%$, sedangkan kadar air terendah pada perlakuan subsitusi tepung terigu dan tempe 80 gr : 20 gr yaitu $13,30 \%$. Berdasarkan hasil analisis kadar lemak kue bay tat dengan perlakuan subtitusi tepung tempe $50 \mathrm{gr}, 20 \mathrm{gr}, 40 \mathrm{gr}$, 60 gr dan 80 gr berkisar antara 5,51\% hingga $6,59 \%$. Berdasarkan hasil analisis tekstur kue bay tat yang tertinggi dengan subtitusi tepung terigu dan tepung tempe 80 gr : 20 gr yaitu $2,1 \mathrm{~mm}$, sedangkan nilai tekstur terendah pada perlakuan subsitusi tepung terigu dan tepung tempe 20 gr : 80 gr yaitu $1,2 \mathrm{~mm}$. Hal ini 
dikarenakan tepung terigu mengandung gluten yang mampu menghasilakan tekstur yang lembut. Berdasarkan rerata uji organoleptik terhadap warna, rasa, aroma dan kenampakan kue bay tat dengan perlakuan subtitusi tepung tempe menunjukkan perbedaan yang nyata. Hasil rerata uji organoleptik warna berkisar antara 1,95 hingga 2,50, uji organoleptik rasa berkisar antara 1,90 hingga 2,25, uji organoleptik aroma berkisar antara 1,95 hingga 2,40 dan nilai rerata uji organoleptik kenampakan berkisar antara 2,00 hingga 2,35. Dimana penilaian panelis terhadap kue bay tat dengan subtitusi tepung tempe berada pada skala suka.

\section{DAFTAR PUSTAKA}

Astawan, Made. 2005. Info Teknologi Pangan Department of Food Science and Technology, Faculty of Agricultural Technology and Enginering, Bogor Agricultural Universit.

Astawan, 2008,..Sehat Dengan Tempe.Panduan Lengkap Menjaga Kesehatan dengan Tempe. PT Dian Rakyat, Jakarta.

Astuti, 2000.Psikologi Perkembangan pada remaja awal.Yogyakarta : Torrent Books.

Cahyadi, W. 2006.Kedelai Khasiat dan Teknologi. Bumi Aksara. Bandung.

Cauvain, SP. 2004. Improving the Texture of Bread.In : Kilcast D (ed.). Texture in Food. CRC Press, Cambridge.

Deman, J.M., 1997, Kimia Makanan, Bandung : Penerbit ITB.
Inayati, I. 1991. Biskuit Berprotein Tinggi dari Campuran Tepung Terigu, Singkong, Tempe Kedelai .Skripsi.FATETA-IPB. Bogor.

Kasmidjo, R.B., 1990. TEMPE : Mikrobiologi dan Kimia Pengolahan serta Pemanfaatannya. PAU Pangan dan Gizi UGM, Yogyakarta.

Kasmidjo. 1990. Tempe, Mikrobiologi dan Biokimia Pengolahan serta Pemanfaatannya. Semarang: Soegijapranata Press.

Nasution, A. 1980. Metode Penilaian Cita Rasa. Departemen IKK, Faperta, IPB. Bogor

Rampengan, V.J. Pontoh dan D.T. Sembel. 1985. Dasar-dasar Pengawasan Mutu Pangan. Badan Kerja sama Perguruan Tinggi Negeri Indonesia Bagian Timur, Ujung Pandang.

Ruku, Subaedah, Idris Haddade dan RD Teguh Wijanarko. 2009. Teknologi Pengolahan Tanaman Pangan. Bultein Teknologi dan Informasi Pertanian, BPTP Sulawesi Tenggara.

Silitonga herman, (2014). Penambahan tepung tempe dan tepung udang rebon dalam pembuatan kukis sukun. Universitas Riau. Pekanbaru.

Smith, A. K and J. Circle, S. 1978.Soybears Chemistry and Technology.The AVI Pub.Company Inc. westport connecticut.

Snyder dan Kwon, 2000,.Soybean Utilization Published. Van Nostrand Reinhold Company, New York.

Snyder and Kwon,.Soybean Untiluzatin.an AVI Book. Published by van Nostrad Rein hold company, New york.

Steinkraus, K.H., 1983. Indonesian Tempeh and Related Fermentation.Dalam: Handbook 
of Indigenous Fermented Foods. UGM, Yogyakarta.

Sutomo, B., 2008. Cegah Anemia dengan Tempe.http://myhobbyblogs. com/food/files/2008/06/. Diakses tanggal 21 juni 2016.

Wiarno, F. G. 1997. Kimia Pangan Dan Gizi. Gramedia Pusat Utama. Jakarta
Winarno F.G. 2004.Kimia Pangan dan Gizi.PT. Gramedia Pustaka Utama. Jakarta

Wolf, W.J., and C. Cowan, J. 1971. Soybean as a Food Source, C.R.C. Press, Ohio 